International Journal of Instruction e-ISSN: 1308-1470 • www.e-iji.net

Article submission code: 20201118094934

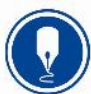

October $2021 \bullet$ Vol.14, No.4

p-ISSN: 1694-609X

pp. 965-984

Received: 18/11/2020

Revision: 11/05/2021
Accepted: 06/06/2021

OnlineFirst: 10/09/2021

\title{
Communicating Lesson Objectives and Effective Questioning in the Mathematics Classroom: The Ghanaian Junior High School Experience
}

\section{Marien Alet Graham}

Assoc. Prof., Department Science, Mathematics and Technology Education, University of Pretoria, South Africa, marien.graham@up.ac.za

\section{Surette van Staden}

Department Science, Mathematics and Technology Education, University of Pretoria, South Africa, surette.vanstaden@up.ac.za

\section{Prosper Dzifa Dzamesi}

Department Science, Mathematics and Technology Education, University of Pretoria, South Africa,dzifadzamesi@yahoo.com

This study reports on Ghanaian junior high school (JHS) mathematics teachers' use of selected assessment for learning strategies in their mathematics classroom. Many JHS teachers may not be familiar with assessment for learning (AfL) strategies to enhance pupils' learning. This qualitative, intervention research employed an educational design research approach to develop hands-on workshops using Wiliam and Thompson's AfL strategic framework to enhance the capacity of the teachers to implement AfL strategies successfully in their classrooms. Eight JHS1 (Grade 7) teachers were purposively selected from JHS' in urban and rural areas. Multiple data collection strategies (interviews, classroom observation, reflective journals and document analysis) were employed to obtain insight into teachers' AfL knowledge, skills and dispositions towards the implementation of learning strategies. The pre-AfL intervention findings showed that the teachers' knowledge of AfL strategies and skills for implementation were inadequate and demonstrated ineffective and limited use of learning strategies when teaching.

Keywords: assessment for learning, effective questioning, lesson objectives, success criteria, mathematics classroom, teaching and learning

\section{INTRODUCTION}

Globally, the practice of assessment has been an ongoing focus of educational research for over a quarter of a century (Callingham, 2008). Traditionally, an assessment was used by teachers mainly to communicate pupils' attainment and also for selecting and sorting pupils for promotion to a new grade (Robertson, 2005, as cited in Malakolunthu $\&$ Hoon, 2010). This traditional, summative (teacher-made quizzes, tests, end-of-term 
examinations) use of assessment is criticized by many scholars (McMillan, 2004; Stobart, 2008; Swaffield, 2011). The scholars assert that this way of using assessment does not improve the learning of pupils. In addition, Black et al. (2003, 2009) mention that the assessment intention that focuses on issuing certificates is outdated; it is not reconcilable with ideas of teaching and learning and does not encourage the learning of pupils. The evidence gathered from pupils during classroom assessment should provide direction for instruction in the teaching and learning process (Hattie, 2012). Black and Wiliam (2009) posit that an assessment, which has the primary aim of supporting the learning and achievement of pupils, is the focus of assessment for learning (AfL). Many scholars (Black \& Wiliam, 1998a, 1998b; Heritage, 2010) in educational assessment have made a compelling case that AfL has the potential to improve achievement scores significantly when teachers intentionally and systematically implement AfL in the classroom. Despite the increasing acclaimed importance of AfL in supporting the learning and achievement of pupils in the classroom, there seemed to be very little evidence in the Ghanaian mathematics classroom with regards to the use of AfL strategies and techniques by the teachers and pupils to support teaching and learning (Awoniyi, 2016; Oduro \& Hudson, 2016). For effective learning to take place, teachers must effectively engage with pupils in the classroom to improve their learning, use assessment information to determine what their pupils have learned and diagnose and assist pupils close learning gaps (Heritage, 2010). The quest to raise the achievement of pupils in schools and to meet the national development agenda prompted educational reforms, which consequently led to reforms in classroom assessments in many nations. Ghana as a nation was involved in several educational reforms that inform assessment policy at the junior high school level.

\section{Assessment in Ghana's Education System}

Until 1987, when the continuous assessment (CA) scheme was introduced in the pretertiary educational system as an assessment module, all schools in Ghana entirely depended on teacher-generated tests and one-shot external examination to measure the performance of pupils. The CA is just a collation of scores of class exercises, homework, projects, assignments, and class tests. These assessment records are used predominantly to place pupils into the next grades of their studies, for certification and employment into the formal job sector (Ampadu \& Adofo, 2014). The CA, which was implemented from primary school to senior high school (SHS) levels, was introduced as a result of educational reform in 1987 which aimed at replacing the one-shot examination system that was then in practice. The CA scores initially formed $40 \%$ of the basic education certificate examination (BECE). However, in 1994, the CA score was reviewed downwards to $30 \%$ by a committee set up by the West Africa Examination Council (WAEC). One of the reasons for the review was that the CA score did not reflect the actual performance of the pupils taking part in the national assessment. According to an inquiry report by Wuddah (1996), a considerable number of the JHS teachers award marks to pupils without carrying out any actual assessment practice, such as testing, in the classroom. 
In 2007, Ghana implemented educational curriculum reforms which proposed, among other things, a change in the assessment practices of teachers in the pre-tertiary education system (kindergarten [KG], primary school, JHS and senior high schools [SHS]) (Anamuah-Mensah, 2008; Curriculum Research Development Division [CRDD], 2012). Because of the reforms in assessment, a new school-based assessment (SBA) was introduced to replace the old CA. The SBA was introduced in the year 2012 at the basic education level (KG to JHS) (CRDD, 2012).

In Ghana, research has shown that teachers' assessment practices are highly summative in focus, and not likely to promote the learning of pupils (Awoniyi, 2016; Bello \& Tijani, 2013). Moreover, the Assessment Services Unit's (ASU) of Ghana Education Service (GES) report of 2008 indicated that teachers' conduct of assessment was ineffective and needed to be addressed. Bello and Tijani (2013) supported the position of ASU by indicating that CA failed to achieve its purpose, as teachers could not use the assessment data to address the learning needs of pupils. In addition, where class sizes were large, teachers resorted to the 'manufacturing' of assessment scores for pupils (Etsey, 2012). The National Education Assessment of 2011 proposed that teachers should be equipped with knowledge and skills on current trends in assessment practices in the classroom to address the deficiency of teachers' ineffective assessment practices (MOE Ghana, 2014).

\section{The Concept of AfL and AfL in Mathematics Classroom}

The literature revealed varying views on the concept of AfL. Presently, there is no clear globally accepted definition for AfL as applied to teaching and learning (Black \& Wiliam, 2006). Despite this absence of a single definition, assessment experts state that AfL is the assessment that informs teaching and encourages learning. Assessment experts in The Assessment Reform Group (ARG) in the United Kingdom, which were tasked to ensure that assessment practice and policy are backed by research evidence, came up with a definition of assessment for learning. These experts defined AfL as "the process of seeking and interpreting evidence for use by pupils and their teachers to decide where pupils are in their learning, where they need to go and how best to get there" (Broadfoot et al., 2002, p. 2). According to this group's definition, evidence of learning must be elicited from pupils, processed and used to promote learning. The ARG (2002) further posited that the involvement of feedback practice alone would not automatically move learning forward, but other factors come into play in the classroom. Regarding the concept clarifications on AfL by ARG, one notices that the AfL concept aims to close the gap of pupil learning by identifying where pupils are in their learning, what they are going to learn and how to get pupils to achieve the intended goals in their learning.

In the mathematics classroom, teachers undertake AfL processes to glean information about the progress of learning that has taken place (Stobart, 2008). The aim is to process the information and use it to address the learning needs of the individual pupils, and also to inform the decisions that need to be made on pedagogical instructions by the teachers. The teacher in the AfL classroom motivates pupils to become active during instructional 
sessions, supports pupils to know where they currently are, understand where they will be going, and how to achieve the new intended learning goals.

\section{AfL Strategies}

Some strategies are relevant to the practice of AfL in the classroom to promote learning and attainment (Black \& Wiliam, 1998a, 1998b; Wiliam \& Thompson, 2014). The presence of these processes or strategies in the classroom is what defines a class as an AfL classroom. This empirical study is guided by five key AfL strategies that support the progression of learning when these strategies are purposefully and effectively implemented in the classroom (Wiliam \& Thompson, 2014). These strategies are (i) clarifying, understanding and sharing of learning objectives and criteria for the successful execution of the task with pupils; (ii) providing effective descriptive feedback to move learning forward; (iii) enforcing effective classroom discussions; questioning the status and initiating activities that draw evidence of learning; (iv) energizing pupils to engage in self-assessment; and (v) activating pupils to be a learning resource for each other (peer assessments). Wiliam and Thompson (2014) proposed a strategic framework for the AfL classroom, as presented in Table 1. Wiliam and Thompson (2014) identified agents (teacher, peer, and pupil) in the classroom and the processes of learning proposed by Ramaprasad (1983) to design the strategic framework for AfL. Although the connected framework structure works in the classroom, Wiliam and Thompson (2014) did not explain the order of the implementation of these strategies or the relationship of the strategies with each other. However, the authors noticed that the framework clearly explains the role played by the teacher, peer, and the pupil during the instructional period to effectively implement the strategies to help pupils to learn and become autonomous in learning. The teacher, who is the key agent for the effective implementation of AfL strategies, needs to have the required knowledge and skills (Swaffield, 2011).

Table 1

The framework for AFL strategies

\begin{tabular}{|c|c|c|c|}
\hline & Where the pupil is going & Where the pupil is right now & How to get there \\
\hline Teacher & $\begin{array}{l}\text { Clarifying and sharing the } \\
\text { learning objectives and } \\
\text { success criteria }\end{array}$ & $\begin{array}{l}\text { Engineering effective classroom } \\
\text { discussions, activities and learning } \\
\text { tasks that draw out evidence of } \\
\text { learning }\end{array}$ & $\begin{array}{l}\text { Effective feedback } \\
\text { that moves learning } \\
\text { forward }\end{array}$ \\
\hline Peer & $\begin{array}{l}\text { Understanding and sharing } \\
\text { the learning objectives and } \\
\text { success criteria }\end{array}$ & $\begin{array}{l}\text { Activating peer-assessments } \\
\text { to support each other } \\
\text { in their learning }\end{array}$ & \\
\hline Pupil & $\begin{array}{l}\text { Understanding the learning } \\
\text { objectives and success } \\
\text { criteria }\end{array}$ & $\begin{array}{l}\text { Activating pupils to own } \\
\text { their learning through } \\
\text { self-assessment }\end{array}$ & \\
\hline
\end{tabular}

Source: (Wiliam \& Thompson, 2014, p. 63)

Conversely, Bennet (2011) and Brookhart et al. (2010) argued that these AfL strategies could be addressed separately or as an individual entity. Though it may be ideal that these strategies are discussed in connection with each other and how they are related in practice, the present study investigated how the teachers implement each strategy during mathematics lessons to promote the learning and achievements of pupils. For the 
purpose of this article, two of the strategies namely: Clarifying and sharing lesson objectives (LO) and success criteria (SC), and teachers' effective questioning to elicit evidence of learning, are discussed. The implementation of the selected strategies comes with their complexities (Bennet, 2010; Swaffield, 2011). Therefore, the reason for reporting on these two strategies is because teachers appeared to have been conversant with stating objective(s) of lessons and questioning in their classrooms. Exploring these strategies is to show that with training, teachers can acquire the relevant skills and be willing to use what they have learned to improve classroom instructions.

\section{Clarifying and Sharing of Lesson Objectives and Success Criteria with Pupils}

The LO vividly identifies what the teacher wants their pupils to know by the end of the lesson, while the SC specifies how the pupils will demonstrate the concepts, skills, and knowledge received (Bartlett, 2015). In other words, SC is the measures used to determine whether, and how well, pupils have met the LO outlined in the lesson. Once a lesson is planned or carefully designed to be taught, the teacher has measurable objectives which guide them to help pupils acquire the concepts, skills, and knowledge mentioned in the lesson plan. The LO clearly specify what pupils are going to learn in a lesson (Moss \& Brookhart, 2012). Teachers should decide on what to teach in the classroom, and the teacher should identify, understand, and specify the LO and the SC. The LO and SC of every lesson could be described as the force that drives the process of AfL (Bartlett, 2015; Heritage, 2010).

Heritage (2010) and Glasson (2009) state that the LO make pupils focus on what they are going to learn rather than the tasks they are going to do. The effort of the teacher to clarify and share LO with their pupils encourages them to become active in the learning process and not be passive recipients of information. The LO and SC are to be communicated to pupils clearly in a language that pupils can understand. Simple terms should be used to clarify the LO and SC to pupils so that they understand the intention of the lesson, and so that they can easily share it with their peers (Heritage, 2010). Pupils thereby become motivated to acquire new skills and knowledge through active participation to avoid rote learning (Harlen, 2007).

\section{Eliciting Evidence of Pupils Learning Through Questioning}

Teachers adopt a variety of approaches to know whether pupils have acquired new concepts, skills, and knowledge appropriately during the lesson. It is an important classroom practice for the teacher to sufficiently elicit evidence of pupils' learning while teaching and learning are on-going in order to adjust if necessary. According to Gewertz (2015), this practice of the teacher is essential in the AfL classroom, because it yields information about what their pupils are learning as they progress. Other views (Heritage, 2010; Wylie \& Lyon, 2015) posit that the evidence of pupils' learning elicited by the teacher should be linked to the LO and SC of the lesson. All information gathered on the pupil's understanding of the concepts under discussion is used to refine and improve the quality of teaching and learning (Winarno et al., 2019).

Teachers' classroom questioning is an approach adopted to gather information on pupils' progress in learning or understanding in the classroom. Yet, according to Bartlett 
(2015), many questions posed by teachers remain lower-order (such as closed-ended questions) instead of higher-order, cognitive development questions (such as openended questions) which have the potential to develop pupils' thinking ability. Webb and Jones (2009) indicated that teachers' familiarity with the habit of questioning in the classroom could have led to teachers not fully appreciating the potential of questions that promote effective dialogue and assist with high metacognition of pupils.

\section{Research Questions}

In this empirical study, eight JHS 1 (Grade 7) teachers participated in an intervention research study with the objectives of exploring these teachers' knowledge and skills to successfully clarify and share lesson objectives and success criteria and questioning practices in their mathematics classroom. In addition, the study aimed to design a handson AfL intervention workshop to equip the teachers to enhance their AfL practices, if deficiencies in their practices are observed.

The questions to be addressed in this research study are:

The primary question is:

How would AfL strategies training improve the knowledge and skills of teachers in JHS1 in the teaching of mathematics?

The primary question is supported by these secondary questions:

1. What knowledge and skills do JHS1 mathematics teachers have to communicate lesson objectives and elicit evidence of learning through questioning in the classroom before they participate in the intervention workshop?

2. To what extent have the JHS1 mathematics teachers changed in knowledge, skills and practice of communicating lesson objectives to their pupils and eliciting evidence of learning through effective questioning in the classroom after participating in the intervention workshop?

\section{METHOD}

\section{Research Design and Participants}

This phenomenological qualitative research study, which employed educational design research (EDR), was conducted in eight JHS in the Hohoe municipality of Ghana. Phenomenology is a qualitative research approach that seeks to describe the essence of characteristics by exploring them from the perspective of those who have experienced it (Teherani et al., 2015). In this current study, the approach sought to describe the essence of the teachers' AfL knowledge and skills by exploring their views regarding AfL practices in the mathematics classroom. Eight JHS 1 teachers were purposefully selected and data collection for the study lasted for four months, from September to December 2018. Public JHS were chosen for the study because all the teachers at this level have at least a diploma qualification in mathematics from the college of education or a degree in mathematics from a university. More so, at JHS level, a teacher is allocated a subject or two to teach (subject teaching), and not as in the primary school 
where a teacher teaches all subjects in a class (class teaching). In addition, pupils at the JHS are also taught and prepared for the standard national examination (Basic education certificate) at the end of their third year at the JHS (i.e., JHS3 [Grade 9]). Selected teachers have at least two years of experience in teaching mathematics at the JHS level to ensure that they are familiar with the content of the curriculum. The pupils in JHS1 in Ghana are approximately 13 years of age and it is their $7^{\text {th }}$ year of schooling. EDR involves the process of designing and developing interventions to address real-world problems (Kelly, 2013; Mckenney \& Reeves, 2012). Consequently, EDR promotes close collaboration between the interventionist researcher and the practitioners. As such, collaboration is vital to enhance the continuous refinement of educational solutions until the problems are resolved (Reeves, McKenney \& Herrington, 2011). The conceptual framework that underpins this research study was developed from reviewing the five key AfL strategies (Wiliam \& Thompson, 2014). The present study went through three main phases, namely pre-AfL intervention (diagnostic), AfL-intervention, and post-AfL intervention. The overview of the profile of the teacher participants is presented in Table 2.

Table 2

Overview of the profile of the JHS1 teacher participants

\begin{tabular}{llllll}
\hline $\begin{array}{l}\text { Participants } \\
\text { (Pseudonym/Codes) }\end{array}$ & Age & $\begin{array}{l}\text { Gender } \\
\text { (male=M; } \\
\text { female=F) }\end{array}$ & $\begin{array}{l}\text { Professional } \\
\text { qualification }\end{array}$ & $\begin{array}{l}\text { Total years of } \\
\text { teaching } \\
\text { experience }\end{array}$ & $\begin{array}{l}\text { Years of } \\
\text { teaching at } \\
\text { current JHS }\end{array}$ \\
\hline SAP1 & 32 & $\mathrm{M}$ & $\begin{array}{l}\text { B. Ed } \\
\text { (Mathematics) }\end{array}$ & 10 & 5 \\
\hline SBP2 & 30 & $\mathrm{M}$ & $\begin{array}{l}\text { B. Ed } \\
\text { (Mathematics) }\end{array}$ & 5 & 2 \\
\hline SCP3 & 26 & $\mathrm{M}$ & $\begin{array}{l}\text { DipEd } \\
\text { (Mathematics) }\end{array}$ & 4 & 8 \\
\hline SEP5 & 40 & $\mathrm{M}$ & $\begin{array}{l}\text { DipEd } \\
\text { (Mathematics) }\end{array}$ & 8 & 2 \\
\hline SFP6 & 32 & $\mathrm{M}$ & $\begin{array}{l}\text { DipEd } \\
\text { (Mathematics) }\end{array}$ & 4 & 5 \\
\hline SGP7 & 35 & $\mathrm{~F}$ & $\begin{array}{l}\text { B. Ed } \\
\text { (Mathematics) }\end{array}$ & 7 & 12 \\
\hline SHP8 & 43 & $\mathrm{M}$ & $\begin{array}{l}\text { B. Ed } \\
\text { (Mathematics) }\end{array}$ & 12 & 9 \\
\hline Note: SAP1 to SHP8 & 38 & $\mathrm{M}$ & $\begin{array}{l}\text { B. Ed } \\
\text { (Mathematics) }\end{array}$ & 11 & 5 \\
\hline
\end{tabular}

Note: SAP1 to SHP8 $\equiv$ school A participant 1 to school H participant 8 (pseudonyms or codes for the teachers). B. Ed $\equiv$ Bachelor of education, DipEd $\equiv$ Diploma in basic education.

\section{Phase I: Pre-AfL Intervention (Diagnosis)}

The pre-AfL intervention phase of the present study lasted for three weeks. It involved one-on-one semi-structured interviews, classroom observations and a review of teachers' lesson plans to gain an understanding of Ghanaian JHS1 mathematics teachers' preintervention knowledge and skills for implementing AfL strategies in the classroom to determine the training needs of the teachers. Having first-hand knowledge of the 
teachers' AfL practices and improving in this direction is critical to enhancing their AfL integration (Acar-Erdol \& Yıldızl, 2018).

\section{Phase II: AfL Intervention}

This phase comprised of three stages where the key five AfL strategies and selected AfL techniques were employed to train the participating mathematics teachers. Three AfL capacity building sessions around the three stages namely; the theory, modeling, and trialing, were organized and attended by the teachers

The theory stage aimed at introducing the teachers to the key five AfL strategies and selected techniques that are adapted to integrate the AfL strategies during teaching and learning. In addition, selected teaching and learning theories that support AfL practices were discussed. The Ghanaian JHS mathematics curriculum and its requirements were reviewed at this stage. This stage was followed by the modeling stage, where the AfL strategies and selected AfL techniques were modeled for the teachers to see how these strategies and techniques are incorporated into mathematics lessons. After several rounds of modeling, reviews and reflections, participants were given the opportunity to plan mini-lessons and practice the knowledge and skills they were exposed to at the workshop during the final stage of trialing. The teachers chose a topic from the mathematics syllabus, planned a lesson indicating the LO, SC, and activities for pupils to undertake in the lesson. The teachers also stated various AfL techniques to use during the lesson to engage all pupils. After every trial, the lesson was reviewed, and constructive oral feedback was provided to the teacher. The post-AfL intervention phase is the third and final of the present study.

\section{Phase III: Post-AfL Intervention}

This final phase focused on the implementation of the knowledge and skills acquired by the participants during the AfL capacity-building workshop into their mathematics classrooms at their respective schools. During the classroom implementation, at least three lessons were observed for each teacher. Before the classroom observation commenced, the teachers' lesson plans were inspected to ensure that teachers incorporated AfL ideas into the plan. After each lesson was delivered, a review was done, and constructive feedback was provided to the teacher to improve upon his or her classroom implementation. The teachers kept reflective journals throughout this phase to document their experiences. Post-classroom implementation one-on-one semi-structured interviews were conducted to gain further insight into how the teachers integrated the AfL strategies in their mathematics teaching, and how their participation in AfL intervention workshops had affected the manner in which they implemented the AfL strategies in the classroom.

A thematic data analysis procedure was applied to the interview data. Other data from the classroom observation, teachers' reflective entries, and teachers' lesson plans were used for data triangulation and crystallization of information. To ensure the trustworthiness of the data, member checking was done. Each participant was presented with his or her transcribed interviews to ascertain whether the content represented his or her view. 


\section{Ethical Consideration}

Ethical approval was obtained from the ethics committee of the Faculty of Education, University of Pretoria, the director of education of Hohoe municipality, and the headteachers of the participating schools. The participating teachers and schools were informed that their participation was voluntary. The teachers were assured of the confidentiality of their personal information. All the participants provided their consent to be part of the research study.

\section{FINDINGS}

Findings on the teachers' practice of only two of the five key AfL strategies researched regarding the teaching of mathematics are discussed. The themes which emerged from the data analysis are presented in Table 3 and subsequently discussed. Research question one (RQ1) is answered by the findings in the pre-AfL intervention phase, while research question two (RQ2) was answered using the post-AfL intervention findings.

Table 3

Themes and source of data

\begin{tabular}{ll}
\hline Themes & \multicolumn{1}{c}{ Sources of Data } \\
\hline Pre-AfL intervention & \\
\hline Clarifying and sharing of LO and SC & $\begin{array}{l}\text { Semi-structured interviews, } \\
\text { Classroom observations, Teachers' lesson plan }\end{array}$ \\
\hline Teachers' questioning practices & $\begin{array}{l}\text { Semi-structured interviews, classroom } \\
\text { observations }\end{array}$ \\
\hline Training needs & Semi-structured interviews \\
\hline Post-AfL intervention & \\
\hline Change in teachers' sharing and clarifying of & $\begin{array}{l}\text { Semi-structured interviews, classroom observations, } \\
\text { Teachers' lesson plan, teachers' journal entries }\end{array}$ \\
LO and SC & $\begin{array}{l}\text { Semi-structured interviews, classroom } \\
\text { observations }\end{array}$ \\
\hline Teachers' effective questioning & $\begin{array}{l}\text { Semi-structured interviews, classroom } \\
\text { practices }\end{array}$ \\
\hline Challenges and solutions & \\
\hline
\end{tabular}

\section{Pre-AfL Intervention Findings}

Clarifying and sharing of lesson objectives and success criteria

The teachers' classroom practices of AfL before they participated in the present study indicated that all the teachers usually had lesson plans for every mathematics lesson. These lesson plans showed the topic to be treated and the objective(s) to be achieved. The lesson plans, however, never indicated the SC that corresponded to the stated LO. Regarding the sharing of the LO, the diagnostic interviews revealed that half of the teachers never shared the LO with their pupils. The following are the selected voices of the teachers:

"No, I don't give [share with] them [pupils] the objectives. I keep the objectives to myself..., I don't do that."

"They will observe themselves [pupils] to know that this is what we have learned today. No, I don't share the objective with them." 
These teachers believed that the LO were for their personal use and that pupils needed to figure out what they were being taught by themselves.

During classroom observations, more than half of the participating teachers began their lesson by writing the broad topic on the chalkboard without the specific LO. The concepts to be learned were not clarified and shared with pupils. The teachers worked through one or two sample tasks or activities and gave their pupils tasks to work on. Though teachers explained to pupils how to go about the activities or tasks, pupils were not made aware of the LO and SC (or how to know they were on the right path towards acquiring knowledge of a concept).

\section{Teachers' Questioning Practices}

Another challenge the teachers experienced regarding AfL practices is the way they used questions in the classroom. Classroom observation data revealed that the teachers mainly used closed-ended questions which required single answers, such as yes or no; without probing further. Open-ended questions, which have the potential to enhance pupils' metacognitive skills development (Wiliam, 2013), were not usually asked. Apart from the use of lower-order questions in the classroom, their practice of questioning itself lacked in the way the questions are spread across the class, and the time allowed for pupils to respond. Questions were not evenly distributed among pupils. More so, the time the teachers allowed their pupils to respond to questions was inadequate for pupils to think and respond. Though all the teachers mentioned that they give their pupils adequate time to think before responding to a question, classroom observation showed otherwise. As indicated by a participant:

"I sometimes give enough time for the pupils to think, but sometimes I only give a few seconds for them [pupils] to think about the question."

Contradicting findings emerged from the classroom observations. During classroom instructions, the pupils were hardly given time to think about questions before being called to respond. Interestingly, pupils who always raised their hands to answer questions were always called to answer, leaving the rest unengaged and inactive. Although it appeared as though teachers had some knowledge about the use of questioning during instruction, their practice revealed a wide gap in their knowledge and actual classroom practice.

\section{Training Needs}

The participating teachers' display of a lack of adequate knowledge and appropriate skills to effectively integrate the strategies of sharing and clarifying LO and SC and effective classroom questioning, indicated an urgent call to train the teachers. They had to be equipped with the appropriate knowledge and skills that would allow them to use these strategies in their mathematics teaching and learning. The inability of teachers to incorporate the selected AfL strategies into their mathematics lessons successfully may be due to the little information provided in the mathematics curriculum about how to implement the recommended AfL practices and inadequate initial teacher-training on AfL strategies. 
The pre-intervention diagnostic interviews provided the teachers with the opportunity to clearly articulate their own needs for AfL capacity building. Allowing teachers themselves to decide what they considered the most important for their professional learning, made them committed to its implementation (Leahy \& Wiliam, 2012). The teachers believed that AfL intervention training would help them to enhance their knowledge and skills to implement AfL effectively as demanded by the JHS mathematics curriculum. In a relevant voice quoted, a teacher expressed the desire to be empowered to implement the AfL strategies effectively in the teaching of mathematics:

“...workshop will help me to get new methods, new ideas of teaching with AfL skills to improve upon the learning of the student to guide them overcome their weaknesses and to identify their strengths."

Another participant indicated the need for AfL capacity building and how this professional learning will equip him to effectively integrate AfL strategies in teaching and learning:

"I need in-service training ... to build my knowledge and skills to do assessment for learning practices well."

The enthusiastic response by the teachers was an indication that they were open to an intervention to improve their AfL practices in the classroom. The support given to teachers to enhance their ability to integrate AfL effectively in the classroom was based on the five key strategies of AfL and some selected AfL techniques (Wiliam \& Leahy, 2012; Wiliam \& Thompson, 2014).

\section{Post-AfL Intervention Findings}

Change in Teachers' sharing and clarifying lesson objectives and success criteria

Having organized AfL capacity-building workshops for the teachers to equip them with relevant knowledge and skills, it was appropriate to appraise the outcome or the effects that the AfL intervention training had on the participating teachers. This appraisal involved the use of one-on-one semi-structured interviews with the eight teachers to discuss how they implemented the AfL strategies and how their participation in the intervention training impacted their implementation of the AfL. In addition, the postAfL intervention phase tried to provide answers for the second research question of the present study being "To what extent have the JHS1 mathematics teachers changed in knowledge, skills, and practice of AfL strategies in the classroom after participating in the intervention workshop?". The information from the one-on-one semi-structured interviews was triangulated with data from classroom observation, the teachers' reflective journals, and teachers' lesson notes (plans).

Before the intervention workshop, although all the teachers stated the LO in their lesson plans, only three shared it with their pupils by writing it on the chalkboard. After the intervention, all the teachers went beyond just writing their LO and SC and shared them with their pupils. This is what one of the participants said:

"Formerly, I don't normally give out the learning intentions [lesson objectives], ... I don't give them the scope but after being introduced to the 
techniques and strategies, this time I write the learning intentions on the board and share with them... I equally state and share the success criteria, which contains almost everything that we are going to do in the lesson."

As indicated by the voice quoted, classroom observation data confirmed that after the workshop, all the participating teachers clarified and shared the LO with their pupils using the read-aloud technique. Though all teachers mentioned in the post-AfL intervention interview how they implemented their intervention knowledge and skills, it was however observed that two of the teachers could not state the SC based clearly on the LO in their lesson plans. In addition, at the initial stage of classroom implementation, five of the eight participating teachers did not share their SC at the beginning of the lesson and throughout the lesson. Upon reviews and reflections all participating teachers, as part of their individual lessons, wrote the LO on the chalkboard, explained them to their pupils, and led them to share among their peers by reading aloud. The majority of the teachers kept reminding their pupils of the $\mathrm{LO}$ and the SC.

\section{Teachers' effective questioning practices}

According to the interview data, more than half of the teachers, six (6), mentioned that they used name sticks as a technique to ensure that pupils were randomly selected and their questions evenly distributed. The teachers further added that they also deliberately employed the wait-time technique to allow pupils to think before answering the questions, and also use name sticks to ensure a fair distribution of questions:

"I don't just ask my question and quickly ask for the answers. I pause at least 3-10 seconds and allow the children to process their answers before I call for a response. I make sure that our questions are not in one way. I have the open ones and the closed ones; those ones that will cause the children to think and think effectively before bringing their answers."

"Before the workshop, there was raising up of hands and some pupils were not even satisfied with the raising of hands, they will be saying Sir call me, Sir, ... but now ..., they are usually quiet and attentive because they don't know whose name will be called on the name stick. So, everybody is attentive thinking about the question."

The teachers' claims were confirmed during classroom observation and a review of their reflective journal entries. During the classroom observation after the capacity-building workshops, it was observed that when the majority of the teachers posed a question to pupils, they paused for a moment (for about 3 to 10 seconds) depending on the demand of the question before selecting a pupil to answer. All the teachers introduced the "no hand up" rule for the pupils not to raise their hands to be called to answer the question. This rule allows the teachers to use the name stick as a technique to randomly select any pupil in the class to answer the question. It took some time for pupils to fully comply with the rule, but as the lessons progressed the raising of hands ceased. Although all the teachers struggled to keep up with the use of the name sticks for randomly selecting pupils to contribute an answer to a question, they became consistent with the use of the sticks throughout their lessons. Additionally, the teachers tried soliciting responses from 
more than two pupils when a question was posed. Moreover, the teachers used the questions to solicit responses that required higher-order thinking, which made children think of alternative ways of solving a problem or prompt pupils to explain their solutions.

\section{Challenges and Solutions}

Despite the steady success of the implementation of the clarifying and sharing of LO and SC and effective questioning to elicit evidence of learning from the pupil, the postimplementation interview data showed that the teachers encountered some challenges during their implementation in mathematics lessons. For example, the teachers had problems using some of the AfL techniques to implement the strategies mentioned. One teacher had this to say: "...there were times I forgot to use the name sticks. This is because I was not used to using them". Another teacher indicated that she had a problem during the initial stages: "I had a problem with stating the SC for the LO at the initial stage."

By triangulation, classroom observation data confirmed the initial challenges that the teachers faced. It was observed that the teachers initially had a problem with how to state clear SC and share this with pupils. The teachers could not write appropriate SC to accompany the corresponding LO. Most of the teachers shared the LO with their pupils, but without the SC. Further, the researchers noticed that during teaching, teachers sometimes forgot to use the name sticks continuously or consistently. On the part of the pupils, there were cases in the classroom where pupils still raised their hands to be called to answer questions. The issue of difficulty in listing their SC was not completely resolved with two of the participants, but the situation was better than it was in the preintervention phase. The inability of the teachers to incorporate the selected AfL strategies into their mathematics lessons successfully may be due to the little information provided in the mathematics curriculum about how to implement the recommended AfL practices and inadequate initial teacher-training on AfL strategies.

\section{DISCUSSION}

\section{Sharing and Clarifying Lesson Objectives and Success Criteria}

The LO articulates the intended learning outcomes of the lesson and describe what pupils should know, understand, and be able to do during and by the close of the period for the lesson need to be shared and understood by pupils (Heritage, 2010; Wiliam, 2013). Clarifying and sharing the LO is as important as any other tool in the teaching and learning process in the classroom (Clarke, 2008; Glasson, 2009). Although the teachers were seen writing the lesson topics on the chalkboard, they did not do the same with the LO. The teachers thought the LO were the sole reserve of the teacher. This faulty thinking made the learners unaware of the direction of the lesson: "No, I don't give them [pupils] the objectives. I keep the objectives to myself ... I don't share it." The lesson objectives were always "out of sight" of the pupils.

The practice of clarifying and sharing LO provides a clear basis for the teachers to track pupils' progress, provide feedback, and assess the achievement of pupils (Bartlett, 2015). In pupil-centered classrooms where pupils have to take responsibility for their 
learning, there is a need for pupils to know and understand what the lesson of the day is about right from the beginning of the lesson (Reed, 2012). This practice makes pupils become active in the lesson and construct knowledge for themselves (Flórez \& Sammons, 2013).

The SC of the LO points out specific skills, knowledge, and understanding that the pupils need to demonstrate as evidence that the lesson objectives have been attained or not. Clearly, teachers' failure to develop, clarify and share the SC with their pupils renders pupils "powerless" to know whether they were on track with the lesson, and also to be able to assess themselves and their peers, if required (Bartlett, 2015; Wiliam, 2013).

\section{Teachers' Effective Questioning Practices}

In the mathematics classroom, dialogue, and interaction between teachers and pupils occur through questioning (Ma, 2008). Questioning is a common practice during teaching and learning. A series of well-planned questions posed by a teacher can quickly illuminate what pupils are thinking. Additionally, effective questioning also helps the teacher to check pupils' understanding of the LO being discussed and promote pupils' active participation in the classroom discussion. During the process, pupils' responses provide the teachers with information about their pupils' understanding and the next direction for the lesson (Albergaria-Almeida, 2010).

The eight participating teachers demonstrated knowledge of the importance of questioning and the distributing of questions among pupils during mathematics lessons. However, there seemed to be gaps between the teachers' knowledge and their questioning practices.

For example, in the present study, it was common practice for teachers only to call a few brilliant pupils who put up their hands to answer questions in class. This showed that the teachers were not using a random response system (RRS) in selecting pupils. The pupils' hand-raising restricts the teachers' ability to effectively elicit evidence of learning from the entire classroom (Udall, 2012). This implied that teachers possibly had a limited idea about all the pupils' progress in the lesson.

The use of any RRS in the classroom engages all pupils, sets the expectation that all the pupils are worth hearing, eliminates favoritism and prevents "hand-raising pupils" from dominating class discussions (Bartlett, 2015; Wiliam, 2013). Moreover, without the effective use of an RRS, all pupils may not actively engage in mathematics lessons, which implies that some pupils were neglected and disengaged in the lesson activities (Wiliam, 2013).

When posing questions in the classroom, wait-time is the time that a teacher allows or waits after a question is posed to call on a pupil to respond (Kelly, 2020; TeacherVision, 2015). In the present study, although all the teachers acknowledged the relevance of wait-time, teachers were observed not giving their pupils any meaningful time to transform and order their responses appropriately. Wait-time, a period of silence between the time a question is posed when a pupil responds to that question, was missing when teachers asked a question. This finding on the ineffective use of wait-time 
in the participating teachers' questioning practice confirms the findings of Kelly (2020). According to Kelly (2020), teachers neglect the regular practice of wait-time during teaching and learning and in effect, deny pupils the space to reason critically.

Waiting for pupils to process their response or teachers to comment on their answers matters in the classroom. The type of response that the teacher requires from their pupils determines the wait-time which could range between three to five seconds (Rowe, 1986; Stahl, 1994) depending on the kind of questions posed to the class. According to Kelly (2020), implementing an effective wait-time of three to five seconds is "purposeful and takes regular practice". The teachers in the present study were uncertain as to how much time they could allow before inviting answers from their pupils. The practice of waittime needs planning, commitment, and regular use during questioning in mathematics lessons to promote critical thinking ability in pupils.

In the classroom, the participating teachers asked more fact-calling (closed-ended) questions than open-ended questions. These closed-ended questions lacked the potential to develop pupils into active, independent and critical thinkers, which open-ended questions could do (Chan \& Clarke, 2017). Pupils were hardly asked open-ended questions or asked to explain their answers to fact-calling questions to stimulate them to think critically (Paramore, 2017). In conclusion, in the present study, the participating teachers over-rely on low-level questions at the expense of more thought-provoking, higher-order questions needed for problem-solving and further lifelong learning and living.

\section{Changes in Teachers' AfL practices}

Three sessions of AfL intervention training workshops planned and organized so that teachers can be equipped with the relevant knowledge and skills were based on the key five strategies of AfL. The participants were equipped with hands-on knowledge and skills to implement the strategies successfully. Model mathematics lessons were planned by combining the strategies and techniques with teachers and delivered during the workshop sessions. The teachers were given the opportunity to implement the workshop knowledge and skills in their mathematics classrooms.

All the participating teachers had noticeably demonstrated a change in their lesson planning to depict their readiness for implementing AfL in their teaching. The majority of teachers now include their SC in their lesson plans and share this with their pupils. In the classroom, teachers were observed clarifying and sharing the LO and SC with their pupils. This AfL practice made pupils aware of what they were going to study during the lesson and kept them attentive and confirmed whether they achieved their LO (Bartlett, 2015; Moss \& Brookhart, 2012). Teachers elicited pupils' understanding and learning using more open-ended questions. Even closed-ended questions were probed further to allow pupils to explain their answers. Pupils no longer raised their hands to be called to respond to teachers' questions since the teachers had changed to the use of RRS such as the name sticks. The RRS helps the teachers to randomly distribute their questions among pupils, providing an opportunity for equal and active participation in the lesson (Wiliam \& Leahy, 2012). Pupils saw the use of RSS as a technique devoid of favoritism 
in the selection of who to answer the teachers' questions. This finding confirmed that of Sondergeld et al. (2010) that pupils expected teachers to be fair in the selection of pupils to respond to questions. The modest use of wait-time and name sticks during mathematics lessons improves classroom interaction between teachers and pupils (Nappi, 2017; Feng \& Wei, 2019). The use of name sticks, among other things, was to discourage pupils from putting up their hands to answer questions in class. A possible explanation for the continuous raising of hands by pupils is that pupils were not familiar with the use of name sticks in classrooms. This challenge was resolved as the implementation was sustained during this study.

The gradual signs of change in teachers' practice of sharing and clarifying LO and SC; and effective questioning in their mathematics teaching and learning could be linked to their participation in the intervention workshops. The teachers had the opportunity to reflect on their practices during the present study and had extra support through teacher learning community (TLC) meetings and 'on the spot' assistance provided by the researchers during the classroom implementation phase.

\section{CONCLUSION}

In the present study, JHS1 (Grade 7) mathematics teachers' knowledge and skills for the implementation of selected assessment for learning strategies were explored. The present study also designed AfL intervention workshops based on the five key assessments for learning (Wiliam \& Thompson, 2014) to equip the participating teachers with relevant AfL related knowledge and skills to implement AfL successfully. The pre-AfL intervention phase findings showed that the teachers seemed to lack the relevant requisite knowledge and skills to clarify and share LO and SC successfully in their classrooms to get their pupils to focus on the lesson to maximize their participation, learning, and attainment. In addition, teachers appeared to lack the capacity to sufficiently and effectively elicit evidence of pupils' learning through questioning during lessons. Therefore, there was a need to equip mathematics teachers through hands-on AfL continuous professional learning workshops to enhance their experience with clarifying and sharing $\mathrm{LO}$ and $\mathrm{SC}$, and also to improve questioning practices to sufficiently elicit evidence of pupils' learning in the classroom. From the post-AfL intervention phase findings, it is evident that the participating teachers reported and demonstrated a change in how they clarify and share LO and SC and a successful change in questioning practices. As a result of changes in the teachers' practices, they reported that pupils became more interested in mathematics learning. Notwithstanding the findings of the present study, a qualitative research approach was employed where the sample size of eight participating mathematics teachers in one municipality was not enough to generalize the findings to all JHS1 mathematics teachers in Ghana. Nonetheless, the findings are convincing enough to make a case for a broader study to be carried out in other parts of the nation. The present study suggests that future research be carried out involving all mathematics teachers in the municipality to gather information on how successfully teachers are communicating and eliciting evidence of learning through effective questioning in the mathematics classroom. Since AfL practices comprise of implementing several strategies and techniques simultaneously, 
we recommend a comprehensive study of the teachers' practices of each of the AfL strategies separately and their impact on pupils' learning and achievement in the Ghanaian mathematics classroom. The efforts of changing pedagogical approaches to teaching and learning are undoubtedly a long-term process, but hopefully, this research study was a step in the right direction for AfL revolution in mathematics education in Ghana.

\section{REFERENCES}

Acar-Erdol, T., \& Yıldizlı, H. (2018). Classroom assessment practices of teachers in Turkey. International Journal of Instruction, 11(3), 587-602. https://doi.org/10.12973/iji.2018.11340a.

Albergaria-Almeida, P. (2010). Classroom questioning: Teachers' perceptions and practices. Procedia-Social and Behavioural Sciences, 2(2), 305-309.

Ampadu, E., \& Adofo, S. (2014). The importance of theoretical underpinning for a school mathematics curriculum: The Ghanaian experience. International Journal of Research Studies in Education, 3(3), 107-118. https//doi.org/ 10.5861/ijrse.2014.715.

Anamuah-Mensah, J. (2008). Teacher education in the context of Ghana's 2007 education reforms. In PRINCOF. Developments in Basic Teacher Education in Ghana (pp. 120-132). Greenland's Concept.

Assessment Reform Group. (2002). Assessment for learning: 10 Principles. Assessment Reform Group.

Awoniyi, F. C. (2016). The understanding of senior high school mathematics teachers of school-based assessment and its challenges in the Cape Coast metropolis. British Journal of Education, 4(10), 22-28.

Bartlett, J. (2015). Outstanding assessment for learning in the classroom. Routledge.

Bello, M. A., \& Tijani, A. A. (2013). Training needs of teachers in school-based assessment in Anglophone West African countries. https://www.iaea.info/documents/paper_2fb24ab5.pdf.

Bennett, R. (2010). Cognitively assessment of, for and as learning (CBAL): $A$ preliminary theory of action for summative and formative assessment. Educational Testing Service.

Bennett, R. (2011). Formative assessment: A critical review, assessment in education. Principles, Policy \& Practice, 18, 5-25.

Black, P., \& Wiliam, D. (1998a). Assessment and classroom learning. Assessment in Education: Principles, Policy \& Practice, 5(1), 7-74.

Black, P., \& Wiliam, D. (1998b). Inside the black box: Raising standards through classroom assessment. Phi Delta Kappan, 80(2), 139-148.

Black, P., \& Wiliam, D. (2006). The reliability of assessments. Assessment and learning, 119-131. 
Black, P., \& Wiliam, D. (2009). Developing the theory of formative assessment. Educational Assessment, Evaluation and Accountability, 21(1), 5-31. https://dx.doi.org/10.1007/s11092-008-9068-5.

Black. P., Harrison, C., Lee C., Marshall, B., \& Wiliam, D. (2003). Formative and summative assessment: Can they serve learning together. AERA Chicago, 23.

Black, P., Harrison, C., Lee, C., Marshall, B., \& Wiliam, D. (2009). In 1998 "Inside the black box," the predecessor of this article, appeared in this journal. Secondary Lenses on Learning Participant Book: Team Leadership for Mathematics in Middle and High Schools, 99.

Broadfoot, P. M., Daugherty, R., Gardner, J., Harlen W., James, M., \& Stobart, G. (2002). Assessment for learning: 10 principles. University of Cambridge School of Education.

Brookhart, S. M., Moss, C. M., \& Long, B. A. (2010). Teacher inquiry into formative assessment practices in remedial reading classrooms. Assessment in Education: Principles, Policy \& Practice, 17(1), 41-58.

Callingham, R. (2008). Dialogue and feedback: Assessment in the primary mathematics classroom. Australian Primary Mathematics Classroom, 13(3), 18-21.

Chan, M. C. E., \& Clarke, D. (2017). Structured affordances in the use of open-ended tasks to facilitate collaborative problem-solving. ZDM, 49(6), 951-963.

Clarke S 2008. Active learning through formative assessment. Hodder Education.

Curriculum Research and Development Division. (2012). National teaching syllabus for junior high school mathematics (JHS1-3). Curriculum Research and Development Division, Ghana Education Service.

Etsey, Y. K. A. (2012). Notes on educational measurement and evaluation. (Unpublished lecture notes). University of Cape Coast, Ghana.

Feng, Z., \& Wei, W. (2019). Study on cultivating students' critical thinking ability through higher order questioning. In $4^{\text {th }}$ International Conference on Contemporary Education, Social Sciences and Humanities (ICCESSH 2019). Atlantis Press.

Flórez, M. T., \& Sammons, P. (2013). Assessment for learning: Effects and impact. CfBT Education Trust.

Gewertz, C. (2015, November 9). Searching for clarity on formative assessment. Education Week. https://www.edweek.org/teaching-learning/searching-forclarity-on-formative-assessment/2015/11.

Glasson, T. (2009). Improving student achievement: A practical guide to Assessment for Learning. Curriculum Corporation.

Harlen, W. (2007). Assessment of learning. Sage.

Hattie, J. (2012). Visible learning for teachers: Maximizing impact on learning. Routledge/Taylor \& Francis Group.

Heritage M. (2010). Formative Assessment: Making it Happen in the Classroom. Sage. 
Kelly, A. E. (2013). When is design research appropriate? In T. Plomp \& N. Nieveen (Eds), An introduction to educational design research (pp. 135-150). Netherlands Institute for Curriculum Development.

Kelly, M. (2020). Wait Time in Education: Giving students a chance to think before responding can boost learning. https://www.thoughtco.com/importance-of-wait-time8405 .

Ma, X. (2008). The skills of teacher's questioning in English classes. International Education Studies, 1(4), 92-100.

Malakolunthu, S., \& Hoon, S. K. (2010). Teacher perspectives of school-based assessment in a secondary school in Kuala Lumpur. Procedia-Social and Behavioral Sciences, 9, 1170-1176. https://doi.org/10.1016/j.sbspro.2010.12.302.

McKenney, S. E., \& Reeves, T. C. (2012). Conducting educational design research. Routledge.

McMillan, J. H. (2004). Classroom assessment: Principles and practice for effective instruction (3rd ed.). Pearson.

Ministry of Education Ghana. (2014). Reforming Science and Mathematics Education in Basic Schools in Ghana. Ministry of Education.

Moss, C. M, \& Brookhart, S. M. (2012). Learning targets: Helping students aim for understanding in today's lesson. ASCD.

Oduro, E. O., \& Hudson, B. (2015, November 18-20). 'Studying mathematics teachers' assessment practices: Implications for teacher education policy and practice in Ghana' [Paper presentation]. In Annual Conference of the Scottish Educational Research Association SERA 2015, at University of Aberdeen, Aberdeen, Scotland https://bit.ly/38c3wS3.

Nappi, J. S. (2017). The importance of questioning in developing critical thinking skills. Delta Kappa Gamma Bulletin: International Journal for Professional Educators, 84(1), 30-41.

Paramore, J. R. (2017). Undergraduate primary education students' experience of assessment: an interpretative phenomenological analysis (Doctoral dissertation, Nottingham Trent University).

Ramaprasad, A. (1983). On the definition of feedback. Behavioral Science, 28(1), 4-13. https://doi.org/10.1002/bs.3830280103.

Reed, D. K. (2012). Clearly communicating the learning objective matters! Middle School Journal, 43(5), 16-24, https://doi.org/10.1080/00940771.2012.11461825.

Reeves, T., McKenney, S. \& Herrington, J. (2011). Publishing and perishing: The critical importance of educational design research. Australasian Journal of Educational Technology, 27(1), 55-65.

https://www.ajet.org.au/ index.php/AJET/article/view/982/255. 
Rowe, M. B. (1986). Wait time: Slowing down may be a way of speeding up! Journal of Teacher Education, 37(1), 43-50.

Sondergeld, T., Bell, C., \& Leusner, D. M. (2010). Understanding how teachers engage in formative assessment. Teaching \& Learning, 24(2), 77-86.

Stahl, R. J. (1994). Using" think-time" and" wait-time" skilfully in the classroom. ERIC Clearinghouse.

Stobart, G. (2008). Testing times: The uses and abuses of assessment. Routledge.

Swaffield, S. (2011). Getting to the heart of authentic assessment for learning. Assessment in Education: Principles, Policy \& Practice, 18(4), 433-449.

TeacherVision. (2015). Your Secret Weapon: Wait time, Teaching methods and Strategies. TeacherVision. https://www.teachervision.com/teaching-methods/newteacher/48446.html.

Teherani, A., Martimianakis, T., Stenfors-Hayes, T., Wadhwa, A., \& Varpio, L. (2015). Choosing a qualitative research approach. Journal of graduate medical education, 7(4), 669-670. https://doi.org/10.4300/JGME-D-15-00414.1.

Udall, A. (2012). Instructional strategies: Raising hands in class and the outlier effect. Teach. Learn. Grow. The education blog. https://www.nwea.org/blog/ 2012/instructional-strategies-raising-hands-in-class-and-the-outlier-effect/.

Webb, M., \& Jones, J. (2009). Exploring tensions in developing assessment for learning. Education: Principles, Policy \& Practice, 16(2), 165-184.

Wiliam, D. (2013). Assessment: The Bridge between teaching and learning. Voices from the Middle, 21(2), 15-20.

Wiliam, D., \& Leahy, S. (2012). Sustaining formative assessment with teacher learning communities. In PERIHA Professional Learning Series Workshop, Ministry of Education.

Wiliam, D., \& Thompson, M. (2014). Integrating assessment with instruction: What will it take to make it work? In C.A. Dwyer (ed.). The future of assessment: Shaping teaching and learning, pp. 53-82. Routledge.

Winarno, Zuhri, M., Mansur, Sutomo, I., \& Widhyahrini, K. (2019). Development of assessment for the learning of the humanistic model to improve evaluation of elementary school mathematics. International Journal of Instruction, 12(4), 49-64. https://doi.org/10.29333/iji.2019.1244a.

Wuddah, A. A. (1996). Incorporating teachers' assessment in the final grade. In WAEC monthly seminar papers, 1996 series.

Wylie, C., \& Lyon, C. (2015). The fidelity of formative assessment implementation: issues of breadth and quality. Assessment in Education, Principles, Policy and Practice, 22(1), 140-160. https//doi:10.1080/0969594X.2014.990416. 